\title{
TITLE OF LAND UNDER WATER IN NEW YORK
}

\section{PART I.}

It has often been decided by the Supreme Court of the United States and by the New York Court of Appeals that in this country the fee title of lands under navigable waters up to the high water mark is vested in the commonwealth or state in which the property is situated, or in its grantees ${ }^{1}$ These decisions are based upon the theory that the state or commonwealth is the logical and legal successor in this country of the sovereign or supreme power of Great Britain, which, before the Revolution, resided in the Crown and Parliament, and held, in the name of the King, the title to all public lands, including lands under water. While it is gradually becoming recognized that the British sovereignty over this country at the time of the Revolution did not split up into thirteen sovereignties and pass to the so-called states, making them "sovereign states" within a state and erecting, for the first time in the history of the world, that impossible political anomaly often described as a "double sovereignty", it is nevertheless true that by the decisions of the highest court the title of lands under navigable water is said to be vested in the state in which it is situated, or its grantees. There is some confusion as to the nature of this title and the extent to which it may be alienated. It will therefore be helpful to a proper understanding of the subject to ascertain exactiy what happened in the transition from colonies to republic.

The Continental Congress met prior to the Declaration of Independence and organized as the representative of all the colonies. This was the first organization of sovereignty in this country. The Congress assembled in May, 1775, in Philadelphia, and adjourned in December, 1776. It was followed by the Congress which met in Baltimore in December, 1776, and continued throughout the Revolutionary War and until the Articles of Con-

${ }^{1}$ Ill. Cen. R. R. v. Illinois. 146 U. S., 387; Gibson v. U. S., 166 U. S., 271; Cummings v. Chicago, 188 U. S., 410; N. Shore Boom Co. v. Nicomen Boom Co., 212 U. S., 406; People v. Tibbetts, 19 N. Y., 523; Roberts v. Baumgargen, 110 N. Y., 380; Gerard on Titles (5th Ed.), 1909; People ex. rel. Howell v. Jessup, 160 N. Y., 256. See also Martin v. Waddell, 16 Pet., 267 ; Pollard v. Hagan, 3 How (U. S.), 212. 
federation went into operation, March 1, 1781. The Continental Congress was a revolutiorrary body representing the whole people of the colonies and not any particular colony alone; it legislated for the whole country, and proclaimed to the world that the American people had become a national state and not thirteen separate states, when they assumed "among the Powers of the earth, the separate and equal station to which the Laws of Nature and of Nature's God entitle them." It was the organization of the American State, and therefore automatically succeeded to all the rights, powers, attributes, and property of the former sovereign. These logically included the title to lands under navigable waters. The next step was the adoption of the "Articles of Confederation"; and when the Continental Congress went out of existence in 1781 the organization of the American sovereign or state also ceased to exist, for the Articles of Confederation provided only for a central government without any organization of state or sovereignty behind it. ${ }^{2}$ This condition continued until the adoption of the present constitution, a revolutionary document, which created an organization of the United States as sovereign or state, independent of the organs of government, and also provided for an organization of the sovereignty or state through instrumentalities of the central and local governments. ${ }^{3}$ It has been said that a state is called a sovereign state when the supreme power resides within itself, whether resting in a single individual, or in a number of individuals, or in the whole body of the people. ${ }^{4}$ It might have been more accurately said that there is no state without this supreme or sovereign power, and that the political organization which exists without it is merely government by whatever name it is called. This leads us to inquire if this supreme power resides in any of the states of the Union? It seems not; and it is difficult to see how any of them can claim to be sovereign or to have succeeded as matter of right by virtue of the Revolution to the rights, privileges and property of the former sovereign. It follows, therefore, that the sovereign or supreme power, undoubtedly was and is, in the United States and not in any one or more of the "States", for the reason that there cannot be more than one sovereign or supreme power or dominion

\footnotetext{
2 Burgess, Polit. Sci. and Const. Law, Vol. 1, 100, 101, 243.

${ }^{3}$ Garner and Lodge, Históry U. S., II, 595; Burgess, Polit. Sci. and Const. Law, Vol. I, 101 et seq. and 142 et seq; Const. U. S., Art. V.

4 Cooley, Const. Lim., 4th Ed., 1.
} 
in any single jurisdiction; and that power, as we have seen, was in, and was assumed and exercised by, the people of the United States as a whole when they assembled in the constituent convention, framed the Constitution and directed its adoption by revolutionary procedure and provided therein for the continuing existence of the organization of the state or sovereign back of the United States government. Furthermore, no one colony had the strength to gain its freedom. It was the force of all the peopie of the colonies that made us independent, and we are not, never were, and never shall be as long as the Constitution lasts, a union or confederation of states, but we are now and always have been a nation, or better still, a popular state, "one and inseparable", organized in the Constitution back of and superior to all local and general governments within our boundaries.

Consequently, whatever rights, privileges, power and property, including the title of lands under navigable water, and riparian rights generally, which remained in the King as an attribute of sovereignty at the time of the Revolution logically should have passed to the United States as the sovereign power in this country. This reasoning with respect to land titles has not been followed by the courts, which have uniformly held that the title of lands under tide waters, - the jus privatum, as it is called,- is in the state or its grantees, as the successor of the British sovereign, except where it had been granted before the Revolution to towns or individuals by royal grants or colonial charters or patents, and not in the United States. This ruling does not seem ever to have been questioned by the United States government and possibly could be justified under the Constitution itself upon the theory that the ownership and right to grant land under water was one of the reserved rights and powers of the states referred to in the Tenth Amendment, but none of the decisions has been based upon this ground. In deciding the case of Martin v. Waddell (16 Pet., 36\%), the Court said:

"And when the people of New Jersey took possession of the reins of government and took into their own hands the powers of sovereignty, the prerogatives and regalities which before be-

- See Trustees of Brookhaven v. Strong, 60 N. Y., 56; De Lancey v. Piepgras, 138 N. Y., 26; Trustees of Brookhaven v. Smith, 188 N. Y., 74; Lewis Blue Point Oyster Co. v. Briggs, 198 N. Y., 287, 229 U. S., 82; Tiffany v. Tozm of Oyster Bay, 209 N. X., 1; Lowndes v. Huntington, 153 U. S., 1. 
longed either to the crown or the parliament, became immediately vested in the state."

So in Pollard $v$. Hagan (3 How., 212), involving the title of land under water in Alabama ceded to the United States by Spain, which had been granted to an individual by patent from the United States, the decision states:

"It was insisted that the United States had, under the treaty, succeeded to all the rights and powers of the King of Spain; and as by the laws of Spain, the King had the right to grant to a subject the soil under navigable waters, that therefore the United States had the right to grant the land in controversy, and thereby the plaintiffs acquired a complete title. If it were true that the United States acquired the whole of Alabama from Spain, no such consequences would result as those contended for. It cannot be admitted that the King of Spain could, by treaty or otherwise, impart to the United States any of his royal prerogatives; and much less can it be admitted that they have capacity to receive or power to exercise them. Every nation acquiring territory by treaty or otherwise must hold it subject to those of the government ceding it."

While not quarrelling with the results of these two decisions that grants of land under water must emanate from the state,presuming it could have been more logically decided that the "reserved powers" clause gives the state government power to make such grants, that by the continued exercise of such power it has become a settled rule of property that they have the right to make them, and that as a matter of convenience it is probably best that they should have such right,-it seems that the Court shared the common error of so many who fail to distinguish beween state and government. Louis XIV knew what he was tlaking about when he said, "L'état, c'est moi." He recognized that there was a power superior to the government and claimed that he was that power. In the United States the sovereignty is in the people of the United States; they are the state, the sovereign, and, by the United States Constitution, they have delegated and enumerated certain powers to the general government and left all the remaining governmental powers to the local governments. John W. Burgess in his work on Political Science and Constitutional Law, (Vol. 2, p. 7,) says: "This appears to many minds like a residuary sovereignty in the local organizations. It requires patient reflection and successful discrimination to attain a point of view from which it is clearly seen that there can be no such thing as a residuary sovereignty; that sovereignty is entire or not at all; 
and that what is left by the state to the local organizations in this matter of distribution, is only the residuary powers of government. *** It requires more than superficial thinking to reach the principle that sovereignty cannot be partly here and partly there. but is a unit undivided and indivisible." If this theory is correct, then it was a case of one sovereign treating with another through representatives duly accredited in accordance with the Constitution when the King of Spain ceded Alabama to the United States, and the royal prerogatives and property passed to and became vested in the other sovereignty which was and is the people of the United States-the nation-and not the people of any state or commonwealth, who. only had such governmental powers over such property as the United States Constitution or custom and usage permitted them to exercise. When the court said: "Every nation acquiring territory by treaty or otherwise must hold it subject to the Constitution $* * *$ of its own government" it endeavored to state a self evident proposition, but its error lay in supposing that the Constitution is the creature of the government, whereas the reverse is the case. The Constitution is the word of the sovereign, the creator of the government; and to say that the people of a state or commonwealth are sovereign is equivalent to saying that a state constitution is superior to the United States Constitution. Pomeroy in his "Introduction to the Constitutional Law of the United States" (3d ed., p. 100), says: "The quality of sovereignty is denied to these local communities; the term 'sovereign states', I deem to be illogical, absurd, opposed to the truth. of history." When he here speaks of "sovereign states" he is of course referring to the so-called states of the Union.

The "reserved powers" clause merely gives to the states a power of attorney to do all such acts of local government for the people as were not delegated by them in the Constitution to the United States.Government; and in this view, as plainly indicated by Art. IV, the state governments are merely the local agents of the whole people of the nation, to govern and carry out in their particular localities the will of the sovereign as expressed in the United States Constitution, the United States Government being the general agent, and this agency, or any part of it including the court-given right of state governments to grant land under water, could be revoked at any time by the people through an amendment of the United States Constitution. On 
the other hand, although it has never assumed to make grants of land under water, the United States Government under the clause permitting Congress to regulate commerce ${ }^{6}$ has assumed supreme control of all tide waters and the land thereunder, for the purpose of improving navigation and regulating commerce; has fixed the lines of bulkheads and piers, the lines of solid filling, dredged channels and otherwise regulated the manner in which the shore front property of the riparian owner could be used and enjoyed; and in fact has acted as if this power to regulate the use of tidal waters as commion highway for the purpose of commerce and navigation,- the jus publicum, - which extends to the control of the land under water also, was vested in the United States. Thus we have by virtue of the Court decisions, a divided title to the lands under water, the jus privatum, or fee, being in the state or commonwealth or its grantees ${ }^{7}$ and the jus publicum, or the right to use and enjoy it for the purposes of commerce or navigation being in the United States. ${ }^{8}$ As the United States is the sole judge of the necessity of using or taking the jus privatum for the purposes of commerce or navigation, it amounts to this: that the United States may appropriate this property of the state or its grantees whenever it sees fit to do so, without compensation. ${ }^{9}$ This power has also been exercised by the state or commonwealth, and has been said to be inalienable in the state or commonwealth ;10 but if it was inalienable in the state how could it have passed to the United States? It is plain that the absurdities of this position and the inconsistencies and confusion in the decisions become more apparent the deeper we go into this subject. The true theory seems to be as indicated above, that the "state" or commonwealth never legally succeeded to the title to land under navigable water, whether jus privatum or jus publicum, what-

${ }^{8}$ U. S. Const., Art. 1, sec. 8, par. 3.

${ }^{7}$ People v. Tibbetts, 19 N. Y., 523; Roberts v. Baumgarten, 110 N. Y., 380 , and cases in following notes.

U. S., 161 ; Chandler-Dunbar Water Power Co. v. United States, 229 U. S., 53, and cases cited; People v. Staten Is. Ferry Co., 68 N. Y., 71-77; Lewis Bluse Point Oyster Co. v. Briggs, 198 N. Y., 287, affd. 33 Sup. Ct. R. (U.S.), 697, 229 U. S., 82.

${ }^{8}$ U. S. Constitution, Art. 1, sec. 8, par. 3; Scranton च. Wheeler, 179

${ }^{9}$ Sage v. Mayor, 154 N. Y., 61; Slingerland v. International C. Co., 169 N. Y., 60; Coxe v. State, 144 N. Y.., 408; Lewis Blue Point Oyster Co. v. Briggs, ante.

${ }^{10}$ Bedlow v. N. Y. F. D. Dock Co., 112 N. Y., 263. 
ever those terms may have been construed to mean; but that the whole title to such land became vested in the people of the United States as the only sovereign power in this country and the successor to the sovereignty after the Revolution, and that by the Constitution, as the last word of the sovereign, the control over such land was delegated by the United States to Congress, its governmental agent, with full power to use and dispose of it for the purpose of regulating commerce; and, further, that under the reserved powers clause of the Tenth Amendment of the Constitution the "state" or commonwealth, as a local governmental agency, has the same power to use and dispose of it, subject only to the superior power of the United States through Congress to use and dispose of it for the regulation of commerce. This paramount authority has been generally recognized by the states, and the attorney general of New York has held in an official opinion that while the title of land under the Hudson River is in the state there is no authority in the state to interfere with the national government in the work of improving that river for the purposes of commerce. ${ }^{11}$ Thus Congress may authorize, without compensation, the prevention of the building of bulkheads and piers and other obstructions, ${ }^{12}$ the curtailment of the riparian owner's right of access to the navigable water, and the destruction or removal of private improvements which interfere with navigation $;{ }^{13}$ such interference, however, being permitted only for. the purpose of regulating commerce or navigation. ${ }^{14}$ But the highest courts, which, as stated before, have ruled that the state owned the fee title, have also held that it did not give the state the right to grant the absolute or fee title to such lands on the ground that the state only holds such lands in trust for the public and cannot part with its control thereof for the purposes of the trust,

11 Opinions Atty.-Genl., 1894, p. 382, and cases cited.

12 People v. Vanderbilt, 26 N. Y., 287, 28 N. Y., 396.

13 Sage v. Mayor, 154 N. Y., 61 ; Scranton v. Wheeler, 179 U. S., 161 ; Gerard, Titles to Real Est., 5th Ed., pp. 935, 938, 939, 943; Gould, Law of Waters, 3rd Ed., pp. 78, 251, 273; Slingerland v. International Contr. Co., 169 N. Y., 60 ; Lezeris Blue Point Oyster Co. v. Briggs, 198 N. Y., 287, affd. U. S. Sup. Court, 33 Sup. Ct. R., 679, 229 U. S., $82^{\circ}$ (incidental destruction of oyster beds by dredging deep water channel); Chandler-Dunbar Water Power Co. v. United States, 229 U. S., 53.

14 Matter City of New York, 168 N. Y., 134. 
"except as to such parcels as are used in promoting the interests of the public therein, or can be disposed of without any substantial impairment of the public in the lands and water remaining."15

The conclusion would seem to be then that a grant of lands under navigable waters below high water mark from the state or commonwealth is not good as against the United States if at any time the United States should decide to use such lands for the purpose of regulating commerce. At least, this is so, as long as the land is covered with water. On the other hand, on this theory of the paramount title of the United States, a grant from the United. States, if necessary for the proper regulation of commerce, under authority of an act of Congress would convey a good title and extinguish all other rights. This method, however, has never been followed, and we must therefore inquire as to the nature of the title abtained from the various forms of grants used by the state in conveying these lands.

\section{PART II.}

State grants should be considered historically, having in view the various acts of the legislature upon the subject as well as the decisions of the courts. The first legislation in New York affecting the subject was the act passed October 22, 1779, Ch. 25, L. 1779 , sec. 13 ( 1 Jones and Varick 44 ), which assumed to transfer the seigniory of all. lands, escheats, etc., which were on July 9, 1776, vested in King of Great Britain to the people of the "state". This was followed by a statute relating to the Commissioners of the Land Office, passed May 5, 1786, Ch. 67 L. 1786, and by Ch. 69 L. 1801, Ch. 74 L. 1813, sec. 14, and Vol. 1, R. L. 292, which enacted that "it shall be lawful for the said commissioners to grant so much of the lands under the water of navigable rivers as they shall deem necessary to promote the commerce of this state; provided always, that no such grant shall be made to any person whatever, other than the proprietor or proprietors of the adjacent lands", and was substantially the same as R. S. (1830) p. 208, sec. 67, excepting that the word "lakes" was there added. By an amendment by Ch. 199 L. 1815, sec. 1, the powers of the commissioners were extended to authorize grants of land. under water of navigable lakes and lands under water surrounding Staten Island,

15 Ill. Cen. R. R. Co. v. Illinois, 146 U. S., at 444, 445; Coxe v. State, 146 N. Y., 408; People ex rel. Howell v. Jessup, 160 N. Y., 256. 
"provided no grant to be made in pursuance hereof shall interfere with any rights of the corporation of the City of New York, nor extend more than five hundred feet into the water from low water mark."

Similar provisions were incorporated into the Revised Statutes of 1830, R. S. 208 , sec. 67 , with the further addition that such a grant made to any person other than the owner of the adjacent upland should be void. This was amended by Chapter 232 of the Laws of 1835, which extended the powers of the commissioners to lands under water, and between high and low water mark in, and adjacent to, and surrounding Long Island and that part of Westchester County lying on the East River or Long Island Sound. Section 2 of said act also provided:

"This act or the act referred to in the preceding section shall confer upon the said Commissioners no other power than to authorize the erection of such dock or docks, as they shall deem necessary to promote the commerce of this state and the collection of reasonable and accustomed dockage from persons using such dock or docks, and the legislature may at any time regulate the same in such manner as they shall think proper."

Section 3 of the same act repeals "so much of article fourth of title fifth of chapter ninth of part one of the Revised Statutes as.is inconsistent with this act."

It is apparent therefore that under the Revised Statutes of 1830 as amended by chapter 232, Laws 1835 , the Commissioners of the Land Office had no power to make or authorize any grants of land under water, but had only the power to authorize the erection of docks to promote commerce, and this power, or franchise, could be given to the owner of the adjacent upland only. The same limitations were incorporated in the second, third, fourth, fifth and sixth editions of the Revised Statutes and in the seventh and eighth editions the Act of 1835, chapter 232, is included and reprinted in full. The said limitations were in force until the passage of the Public Lands Law, Chapter 317, Laws 1894, on April 4, 1894, when the act of 1835 was repealed. The statute was also amended by Chap. 283, L. 1850, which gave the Commissioners of the Land Office "power to grant in perpetuity or otherwise so much of the lands under the waters of navigable rivers or lakes as they shall deem necessary to promote the commerce of this state, or proper for the purpose of beneficial enjoyment of the same by the adjacent owner, but no such grant shall 
be made to any other person than the proprietor of the adjacent lands, and any such grant that shall be made to any other person shall be void." The second section of this act extended the power to grant lands under water in, adjacent to and surrounding Long Island and all that part of Westchester County on the East or Hudson River or Long Island Sound, limited such grants to the exterior water line established by. law and excepted lands under water belonging to the City of New York and the rights of the Hudson River Railroad Company. As stated before, the Revised Statutes of 1852, fourth edition and subsequent editions, contained the same limitation upon the powers of the commissioners; and it would seem, therefore, that between the enactment of chapter 232 of the Laws of 1835 and the Public Land Law in 1894 the Commissioners of the Land Office had no power to authorize grants of land under water which would convey a fee title to such lands. Prior to 1835 it seems to have been otherwise, for the attorney-general, in an official opinion, Senate Document No. 45,1832 , states that "grants of land under water have uniformly been made without pecuniary consideration, or any other advantage to the state than such as should result from the promotion of commerce. The letters patent issued in such cases have been in the form usially employed for conveying an estate in fee, and with few exceptions contained no condition or reservation." In 1891 Attorney-General Tabor, in construing the meaning of the phrases "purposes of commerce" and "beneficial enjoyment" in the act of 1850 , Ch. 283 , held that the legislature meant by the latter phrase to authorize the conveyance of a fee "where the land granted was not necessary for the purposes of commerce." It does not appear, however, that he considered the limitations placed upon the powers of the commissioners by the earlier act of 1835 which were then operative, said act not having been repealed until Ch. 317 L. 1894 went into effect. (See Reports Attorney-General, 1891, p. 273.) He seems to assume, if the land granted was "necessary for the purposes of commerce", - presumbly by the state or public, - that the beneficial enjoyment" grant would not convey a fee title; but as nearly all of these grants, especially about the City of New York, are of property which is constantly in use "for the purposes of commerce", and upon which valuable docks, piers and warehouses have been built, and as in nearly every instance the very reason for obtaining the grant is the necessity of erecting upon the land under 
water these aids to commerce and of using the land for the purposes of commerce, the position taken appears to be a little inconsistent. Is it not more likely that the legislature by the Act of 1850 , Ch. 283, intended by the use of the words "beneficial enjoyment" that such a grant should only relieve the grantee from the supervision and control of the legislature in the regulation of the collection of dockage, to which by law he would be subject under the other form of grant, and not to divest the state of title; so that the effect of such a grant would be that the grantee could have, hold and enjoy the land included in it exclusively without interference from the legislature until such time as the public interests require that the state, for the purposes of commerce, should reclaim the land? It would seem so, especially as the limitation upon the powers of the commissioners was continued as sections 84 and 85 , Vol. 1 , R. S. (4th Ed.), p. 451, published in 1852, and subsequent editions down to the act of 1894, when it was repealed. He alse states that in grants for the purposes of commerce only a nominal sum has been charged whereas in grants for beneficial enjoyment the full appraised value has been required. Many local and special acts have been passed relating to this subject. Among them Ch. 156 L. 1848 and Ch. $313 \mathrm{~L}$. 1850 , giving the owners of certain uplands the right to fill in, and it has been held that when this was done it was an artificial accrtion and a gain to the owner of the upland, and that there remained no public easement in the filled-in land, Wetmore $v$. The Atlantic White Lead Co., 37 Barb., 70; but these acts were claimed to be unconstitutional and void because not passed by a two-thirds vote in Wetmore v. Brooklyn Gas Light Co., 42 N. Y., 384. The question, however, was not decided, the court merely holding that the owner's title could not be questioned by any one but the state, and that the public could not land at his dock without permission.

Another local and special act was Ch. 184 L. 1851, which permitted owners of lands fronting en the water in the Sixth, Eighth and Tenth Wards of the City of Brooklyn to construct wharves, bulkheads, piers and basins on the land under water in front of their lands and to charge wharfage. This act merely conferred a license or franchise upon the persons who complied with its terms.

By Ch. 121 L. 1855 , sec. 2, the Commissioners of the Land Office were prohibited from making any grants of land under 
water in respect of which the Harbor Commissioners of the Port of New York were by said act required to report, but this prohibition was repealed by Ch. 360 L. 1858.

Many other and private bills have been passed by the legislature affecting lands under water, such as bills establishing bulkheads, and lines of solid filling; confirming earlier patents, and in some cases specifically conferring the title of such lands upon compliance with the terms of the act. All of these laws must be considered with reference to the particular facts in each case. For instance, some of these laws purport to confirm patents which had been granted "for the purpose of commerce" only and to enlarge them into titles in fee simple, and this has been done even where the terms of the original grant had not been compiied with; others attempt to confer title upon parties holding under patents which were made to persons other than the owners of the adjacent upland, or upon parties holding under a specified grant, although the terms of the grant had not been complied with and the upland title had been severed from the title of the land under water, as where the grantee from the state having acquired his patent of the land under water adjacent to his upland never attempted to comply with its terms, but conveyed his upland with part of the adjacent land under water to one party and later conveyed the balance included in his patent to another. In such a case the first party who had obtained the conveyance of the upland, under the decisions, would be the only one entitled to receive a confirmatory patent or the benefits of remedial legislation, for the reason that all riparian rights are incident to riparian ownership and pass with such ownership and cannot be severed from it. (Ill. Cen. R. R. v. Illinois, 146 U. S., 444; Yates v. Milzereakee, 10 Wall, 497 ; Archibald v. N. Y. C. \& H. R. R. Co., 157 N. Y., 574, 579; Inter City Realty Co. v. Newman, 128 App. Div., 195, 198; B. M. Co. v. P. S. I. Works, 129 N. Y., 155; Chaplain v. Valentine, 19 Barb., 484; People ex 1 el Blakeslee v. Commissioners, 135 N. Y., 447; Matter of City of Buffalo, 206 N. Y., $319,331,338$.) These confirmatory acts of the legislature should be scrutinized closely with a full view of all the facts relating to the upland title, for many of them undoubtedly have been passed without proper investigatien and merely for the purpose of bolstering up a title known to be worthless. Bearing in mind that there is no authority, either at common law or by statute, in the legislature to make grants of land under water to anyone except 
the owner of the adjacent upland which would interfere with his access to the water, and that no consideration passes. to the state for these confirmatory laws, it is difficult to see how they could be sustained or, at least, inure to the benefit of anyone but the owner of the adjacent upland. The legislature has no more power to give away land under water belonging to the state than it has to give away the Capitol at Albany. If, however, the party claiming the benefit of the act is the upland owner or one entitled to succeed to his interest in the land under water and the act imposes conditions upon him to be performed, such as filling in or building docks, then his title would be upheld, upon compliance with the conditions, under the doctrine laid down in Wetmore $v$. Atlantic White Lead Co., 37 Barb., 70; Wetmore v. Brooklyn Gas Light Co., 42 N. Y., 384; Steers v. Brooklyn, 101 N. Y., 51, and Williams v. Mayor, 105 N. Y., 419, provided always that the act complies with the constitutional restrictions that every bill appropriating money or property for a local or private purpose must be passed by a two-thirds vote, and contain in its title a brief statement of its object. Johnson v. Spicer, 107 N. Y., 185, 202, $203 ;$ McCabe v. Kenney, 52 Hun., 514; Kelly v. Pratt, 41 Miscl., 31, 35; Secs. 16 and 20, Art. 3, Constitution.) Also, it would seem, under the doctrine of "artificial accretion" laid down in Wetmore v. Atlantic White Lead Co., above cited, that where the owner of the upland, having a grant from the state of the adjacent land under water, partially complies with the conditions of his grant by filling in a portion of the land under water and then conveys the upland with a part of the filled-in land, retaining a strip of the made land along the new high water mark, he or his subsequent grantee would be in a position as an upland owner to apply for a confirmatory grant from the new high water mark out to the bulkhead line, or to receive the benefit as an upland owner of a confirmatory act of the legislature. See also Williams v. Mayor, above cited, and Bedlow v. N. Y. Floating Dry Dock Co., 112 N. Y., 263. If, however, the filling by the upland owner had been done without the authority of a patent or an act of the legislature it would be a mere nuisance and no title to the land filled in would have been acquired. Sanders v. N. Y.C. \& $H$. R. R. Co., 144 N. Y., 75; People ex rel Blakesley v. Commissioners, 135 N. Y., 447 ; People v. D. \& H. Co., 75 Miscl., 322; People v. Vanderbilt, 26 N. Y., 287; People z. N. Y. S.S. I. Ferry Co., 68 N. Y., 71 ; People v. Vanderbilt, 18 N. Y., 396. Conse- 
quently, where the filling was without authority, a conveyance of the upland with a part of the filled-in land not extending to the water would give to the grantee all of the riparian rights appurtenant to the upland owner, including the right to apply for a patent of the land under water from the original high water mark out to the bulkhead line, or receive the benefits as upland owner of any acts of the legislature relating to such land under water, and the grantor would retain no interest in the strip of made land along the water, although he expressly reserved it or the bounds of his description did not inclucle it. This is upon the theory that the riparian owner cannot sever his riparian rights from the upland, and that land filled in without authority still remains land under water as between him and the state. Sanders v. N.Y.C. \& H. R. R. Co., 144 N. Y., 75 ; People ex rel Blakeslee v. Commissioners, 135 N. Y., 447 ; People v. D. \& H. Co., 75 Miscl., 322; Burbank v. Fay, 65 N. Y., 57. The Public Lands Law, Ch. 317 L. 1894 , Ch. 46 Consolidated Laws, embodies the powers of the Commissioners of the Land Office, and the charter of the City of New York grants to the city land under water embraced by projected streets in public use or which may hereafter be opened for public use. Matter of McClellan, 146 App., 594. It has also been claimed that certain colonial charters vested the title of lands under water within their boundaries in the towns or cities to which they were granted to the exclusion of any title in the state. Thus it has been claimed that under the charters of Brookhaven, Hempstead, Huntington, Gravesend, Flatlands, Flatbush and Bushwick the lands under water in Port Jefferson Bay, Hempstead Harbor, Huntington Harbor, Gravesend, Sheepshead and Jamaica Bays and Bushwick Inlet were granted to the towns. (See People v. Schermerhorn, 19 Barb., 540; Town of Brookhaven v. Strong, 60 N. Y., 56; People v. Jessup, 160 N. Y., 249; Sandiford v. Tozen of Hempstead, 186 N. Y., 554; Southampton v. Mecox Bay O. Co., 116 N. Y., 1; Lowndes v. Huntington, 153 U. S., 1; Oelsner v. Nassau L. \& P. Co., 134 App., 281 ; Town of Brookhaven v. Dyett, etc. Co., 75 Miscl., 311; but see, contra as to Jamaica Bay, Rockaway Park Imp't. Co. v. City of New York, 140 App. Div., 160.) The City of New York has now succeeded to the rights of such of these towns as lie within its limits and by Ch. 568 L. 1909 has acquired the state's title to the lands under water in Jamaica Bay upon certain conditions. It is often difficult to define the exact limits of the boundaries of these colon- 
ial charters, especially so in Gravesend Bay, and the safest course is to require title to be made both from the state and town or city.

\section{PART III.}

The manner in which letters patent in the state of New York have heretofore been executed is also open to criticism. In the year 1803 the Governor of the state was a member of the Commissioners of the Land Office (see Ch. 67 L. 1786, I Green., 280), and by Ch. 42 L. 1791, sec. 2, he was expressly authorized to "issue" letters patent for certain unappropriated lands, excepting "the lands in the southern district of this state" and certain other lands, and these acts do not seem to have been expressly repealed (Unconsolidated Laws, Vol. 1, pp. 15, 46). He presided at the meetings of the board, but by Ch. 88 L. 1803, p. 399, he was relieved from that duty by a provision that in his absence at any meeting the commissioners should appoint a chairman, "provided, always: That the consent and approbation of the person administering the government of this state shall be and hereby is declared to be necessary to the validity of every act and proceeding of the said land office". By Ch. XI L. 1814, sec. V (p. 10), it was declared that thereafter it should not be necessary for the person administering the government to attend any meetings of the commissioners and that thereafter the officer first named in the act amended and attending should preside, but the consent and approbation of the Governor still remained as an essential to the "validity of every act and proceeding of said land office". Since this enactment in 1814, however, the records of the board show that the minutes have not borne the approval of the Governor, which was customary before that date, and the Governor has not since then acted as a member of the board, although he continued to sign and execute letters patent as evidence of his approval, the statute requiring his approval not having been repealed until February 17, 1909, when it was specifically repealed in the Schedule of Laws Repealed at the end of the Public Lands Law, Consolidated Laws, Ann. Ed., pp. 4604 and 4614. The strange thing about this is that since 1894 the law, in addition to giving the commissioners power to make grants, specifically provided that the commissioners may execute conveyances; and, as all authorities agree that in conveyancing the word "execute" means to sign, seal and deliver, it would seem that letters patent, 
since that date, and possibly from the time the Governor was removed from the board by the Constitution of 1846 (Art. V, sec. 5 ), should properly have been signed by all or at least a quorum of the board instead of by the Governor. It was not until 1907, however, that it occurred to any Governor that it was a queer proceeding to ask him to sign patents issued by a board of which he was not a member. Possibly they believed prior to that date that they were "sovereign governors" exercising the royal prerogatives of their "sovereign state" in executing grants of state lands contrary to law; but in 1907 there was an awakening when Governor Hughes refused to sign letters patent on the ground that he should not be required to endorse the proceedings of a board of which he was not a member. It will be remembered that the Governor had been excused by law from attending the meetings of the board as early as 1814; and the Constitution of 1846 provided that "the lieutenant-governor, speaker of the assembly, secretary of state, comptroller, treasurer, attorney-general and state engineer and surveyor shall be the commissioners of the land office"; but it had been customery for the Governor to execute these patents. When Governor Hughes took the position that he was not charged with the duty of executing letters patent, the land board applied to Attorney-General Jackson for advice, and in an interesting opinion (Report of Atty.-Gen'l., 1907, p. 635 ) was told that the "consent or approval of the Governor is no longer required to give validity to such acts, and the Act of 1803", above quoted, "must be deemed repealed by implication", and that "it is undoubtedly within the power of the commissioners of the land office at this time to change the form of letters patent and to authorize one of their number to execute or subscribe the same". The board then passed a resolution authorizing the lieutenant-governor to sign all letters patent. This leads us to inquire, when did the repeal by implication of the Act of 1803 requiring the Governor's "consent and approbation" take effect? Surely it was not when Governor Hughes refused to sign. Was it at the time of the enactment of the Public Lands Law in 1894, which repealed all of Part 1 , Ch. IX, title 5, R. S., except secs, 15,54 and 76 , or, before that time, when the Governor was first definitely removed from the board? If so what becomes of grants signed by the Governor since the repeal by implication took effect and the Governor's consent was no longer necessary to the validity of a grant? This is especially interesting with respect to water grants where the state might claim that conditions were 
not carried out and would be permitted to take advantage of any defects on the ground that grants by the state are construed strictly against the grantee, who deals with a public board at his peril, and must look well to their powers and the validity of their proceedings. (Throop on Public Officers, secs. 105, 106, 110.) Also, if the Act of 1803 was not repealed by implication, what effect will it have on letters patent issued without the Governc approval between 1907 and the date when it was expressly repealed by the Consolidated Laws? Will the court hold these grants void?

The remaining questions involve the legality of the present method of executing patents by the lieutenant-governor alone in face of the express provision of the statute that the commissioners execute the conveyance. The only ground upon which this can be upheld is that the essential act is the resolution of the board to make the grant and its passage by the secretary of state, and that the execution of the grant is a mere ministerial act which the board may delegate to one of its members. This is not a strict compliance with the law, however, and it might well be questioned whether the grantee acquires a marketable title, on the ground that the commissioners are constitutional officers ancl art acting as trustees and must act strictly in accordance with statute, and cannot delegate their powers to one of their number. Sec. 2, Part 1, Ch. IX, title 5, R. S., provided that, "All the powers now vested or hereafter to be vested in the commissioners, may be executed by a majority of the board, or by any three of them, if the surveyor-general be one of such three". Does not this section apply to the signing of letters patent? This was repealed by the Public Lands Law, October 1, 1894, Ch. 317 L. 1894, which provided that three members of the board, including the state engineer or in his absence, a majority of the commissioners, shall constitute a quorum, but there is no provision whatever regarding the right to delegate the powers of the commissioners to execute grants per secs. 62 and 70 , to one or more of their number, much less to an officer who was not a member of the board, as was formerly done, unless it can be inferred from section 4, which is as follows: "Letters patent; form and contents.-All letters patent shall be in such form as the commissioners direct, and contain an exception and reservation, of all gold and silver mines." This is rather far-fetched, however, as this section relates solely to the form of the letters patent and not to the manner of their execution, especially so in view of the 
provisions of sections 62 and 70 , authorizing the commissioners to "execute" and "grant", and the further fact that before the Public Lands Law, by section 38 and other sections of Part 1, Ch. IX, title 5, R. S., it seems to have been contemplated that the commissioners should "issue" such grants. Moreover there was never any resolution of the land board authorizing the Governor to execute grants.

Following is the letter of Governor Hughes presented at a meeting of the Commissioners of the Land Office, December 19, 1907, by the lieutenant-governor, which will be found at p. 231 of Proceedings Commissioners of Land Office, 1907 :

"State of New York, Executive Chamber, "Albany, December 19, 1907.

"To the Commisioners of the Land Office, Albany, N. Y.

"Sirs:-It has been the practice of the Commissioners of the Land Office to present to the Governor for execution on behalf of the state the various grants which they decide should be made. The Governor, however, is not one of the Commissioners of the Land Office, and no authority is vested in him by the Constitution or the statutes to pass upon the merits of any application for the grant of lands or rights in land, or to approve or disapprove the transactions of the Commissioners.

"It seems to me advisable, therefore, that the Commissioners of the Land Office should make such provision for the execution of their grants as will make it unnecessary for the Governor to execute them. In saying this, I do not desire to be understood as expressing disapproval of any action of the Commissioners of the Land Office, for under the law I am not in a position where I would have any right to deal with the merits of any application before them. It is simply my desire that, as they have full authority in the premises and the Governor has no proper relation to the matter, they shall provide independently of the Governer for suitable execution of the grants upon which they decide. I remain,

"Very respectfully yours, "Charles E. Hughes."

On motion, the matter was referred to the Attorney-General, who on December 23, 1907, rendered the opinion above referred to (Id. 234). The questions still remain, did they make proper provision for the "suitable execution of the grants upon which they decide" and are the grants executed by the Governor before 1907 valid?

New York.

Charles G. Stevenson. 